\title{
O Uso da Variável "Raça" na Pesquisa em Saúde
}

There are no other differences than gradual differences between different grades of difference and no difference

William James

JOSUÉ LAGUARDIA ${ }^{l}$

Nos últimos anos, um interesse crescente tem sido observado no uso das categorias raciais e étnicas na Saúde Pública. Entretanto, isso não tem sido acompanhado por um aprofundamento da discussão dos problemas teóricos e práticos relacionados à utilização da variável "raça". Embora o conceito biológico de "raça" ainda tenha forte apelo entre os pesquisadores da área, vários estudos têm proposto outras formas de definir o conceito e estabelecer seu uso na pesquisa em saúde. Neste artigo, busca-se delinear as implicações analíticas das diferentes definições e usos de "raça" e etnicidade na pesquisa em saúde, bem como apontar seus limites e potencialidades.

Palavras-chave: "Raça"; etnicidade; pesquisa em saúde. 


\section{Introdução}

Ao longo das últimas décadas, vários estudos têm revelado diferenças raciais marcantes na morbi-mortalidade, no comportamento em face da doença e da saúde, no acesso e uso dos serviços de saúde, bem como em outras questões de interesse para os pesquisadores em saúde (LILLIE-BLANTON et al., 1996). Entretanto, ao mesmo tempo em que se incentiva que pesquisas em saúde avaliem tais diferenças (SATEL, 2002), com visível aumento das investigações que incluem as variáveis "raça", etnicidade ou grupo étnico (AFSHARI \& BHOPAL, 2002), há ainda dúvidas quanto à validade do uso de tais variáveis (FULLILOVE, 1998; GILROY, 1998). Mesmo entre os profissionais familiarizados com a discussão crítica sobre os efeitos da desigualdade na saúde das populações, ainda há questionamentos sobre a pertinência do uso da "raça" nas pesquisas em saúde, por não saberem o que ela realmente mede, como coletar esse dado e quais as categorias raciais mais adequadas para a classificação.

As críticas à classificação racial baseiam-se, fundamentalmente, na demonstração do caráter ideológico subjacente ao conceito de "raça", parte de uma teoria geral baseada no sistema lineano de taxonomia das espécies. Vários autores concordam que as divisões tipológicas da humanidade em grupos raciais discretos são, em larga medida, arbitrárias e artificiais. Construídas a partir do senso comum, tais divisões acarretam graves consequiências para a vida de indivíduos e grupos, ao serem incorporadas a práticas políticas e legais discriminatórias, afetando o acesso à educação, as formas de emprego, os direitos políticos e a experiência subjetiva (MARSHALL, 1993; WASHBURN, 1993; STEPAN \& GILMAN, 1993; WILLIAMS et al., 1994; WITZIG, 1996; ASPINALL, 1998; DYSON, 1998; KAUFMAN, 1999). Entretanto, o impacto das discussões sobre questões conceituais e metodológicas relativas à "raça" ainda é limitado entre os profissionais da saúde pública e da epidemiologia (JONES et al., 1991; WILLIAMS et al., 1994; KAUFMAN \& COOPER, 1995; HERMAN, 1996; BHOPAL, 1997; WILLIAMS, 1997; McDERMOTT, 1998; PFEFFER, 1998). Muitos desses profissionais conduzem pesquisas e escrevem artigos, assumindo que as "raças" são entidades geneticamente definidas, distinguíveis com base em critérios de diferenças físicas, sem considerar necessário justificar ou discutir a designação dos indivíduos a essa ou àquela "raça" (SHRIVER, 1997; SCHWARTZ, 2001; KAUFMAN \& HALL, 2003). 
Muitas vezes tais classificações são refinamentos de tipologias usadas por leigos, baseadas em pressupostos relativos à distribuição de características genéticas que se supõem existir sob variações fenotípicas escolhidas arbitrariamente (CROW, 2002). Como exemplificam bem algumas desordens da hemoglobina, em particular a anemia falciforme (DYSON, 1998; TAPPER, 1999), a relação entre genótipo e fenótipo não é simples, e diferenças marcantes no fenótipo estão sujeitas a pequenas variações no genótipo. A ênfase no caráter biológico da "raça" tem sido atribuída ao trabalho ideológico de um determinismo genético simplista, que busca isentar de responsabilidade as estruturas políticas e sociais que estariam na origem de certos estados patológicos, naturalizando a discriminação e provendo uma racionalidade científica para a exploração daqueles em situação de inferioridade (KAUFMAN \& HALL, 2003). O que não é freqüentemente reconhecido é o fato de que as "raças" sobre as quais muitos cientistas falam e escrevem são aquelas percebidas e delineadas por grupos particulares de pessoas que interagem em dados contextos históricos e geográficos, nos quais características raciais são definidas por conveniências sociopolíticas (NOBLES, 2000; BASSET, 2000).

Há autores (BHOPAL \& DONALDSON, 1998; GRAVES et al., 2001) que acreditam que a maneira como operacionalizamos as questões relativas à "raça" dos participantes de uma pesquisa pode levar a dois caminhos: reforçar mudanças necessárias para eliminar as desigualdades em saúde ou perpetuar uma noção reificada de "raça", racializando indevidamente certas doenças. Para que os profissionais de saúde possam aperfeiçoar o modo como incluem e trabalham "raça" como variável de seus modelos explicativos das desigualdades em saúde, é preciso que fundamentem suas discussões aparentemente técnicas, tendo como base os aspectos biológicos, históricos e políticos que interagem na construção do conceito de "raça" e sua utilização em distintos grupos sociais.

Este artigo pretende sistematizar e analisar, a partir de uma revisão da literatura em saúde pública e epidemiologia, o papel da variável "raça" em estudos em saúde, ressaltando: (1) o caráter polissêmico do conceito de "raça"; (2) os aspectos biológicos, históricos e políticos de sua construção e operacionalização; e (3) os limites e potencialidades do seu uso na pesquisa em saúde. Para tanto, realizou-se busca em livros-texto, bases de dados bibliográficos (MEDLINE, Scielo, LILACS) e em sítios de busca da Internet, selecionandose artigos que abordassem esse tópico.

No âmbito do sistema de saúde brasileiro, a importância da discussão 
se deve, por um lado, à recente introdução da variável raça/cor nos bancos de dados dos sistemas nacionais de informação do Ministério da Saúde e, por outro, ao número restrito de artigos relativos ao tema publicados em periódicos nacionais de Saúde Pública e Epidemiologia. Tendo em vista a extensa literatura existente sobre o assunto, não serão aprofundadas as discussões acerca das relações raciais no Brasil $^{3}$. Vale ressaltar aqui o papel que a idéia da mestiçagem, em conjunto com três mitos fundantes - o mito das três "raças", o mito da democracia racial e o mito do branqueamento - desempenham na construção de conjunto de saberes e de estratégias de ação, como dispositivo de poder que pauta as discussões acerca das relações raciais e racismo no Brasil, a construção da identidade nacional e a comparação da situação racial brasileira com a de outros países. Como destaca Maggie (1996, p. 226), "esses mitos criam a linguagem da mistura, da indistinção no ideal de branqueamento e organizam o discurso da sociedade como um todo, afetando pessoas de todas as classes e cores".

\section{Aspectos Históricos do Conceito de "Raça"}

O advento das teorias racialistas no século XIX modificou a percepção das diferenças físicas entre os membros da espécie humana, transformando-a em um projeto teórico universalizante que naturalizava essas diferenças, estabelecendo correlações entre as características fenotípicas e atributos morais (TODOROV, 1993; SCHWARTZ, 1993 e 1996). Como aponta Schwartz (1996), esse projeto retirava tais diferenças do âmbito incerto da cultura para o nicho seguro da ciência biológica determinista. No mesmo contexto histórico em que a escravidão era combatida, sob o impacto das mudanças econômicas e da pressão moral, pensadores europeus e norte-americanos articulavam teorias sistemáticas de diferenças biológicas inatas entre as "raças". As teorias históricas de Arthur de Gobineau, sobre a degeneração pela mistura das "raças", eram apoiadas pela antropologia "científica", pela antropossociologia de Gustave Le Bon e Georges Vacher de Lapouge e pelas doutrinas darwinistas sociais predominantes na Inglaterra e EUA (BANTON, 1979; WIEVIORKA, 1992; GOULD, 1993).

Independentemente da perspectiva histórica que se adote, a maior parte dos historiadores da "raça" situa o grande avanço da mesma no século XIX, com sua combinação de colonialismo, de desenvolvimento científico e industrial, do crescimento das cidades, da imigração (e paralelamente da individualização) 
e da ascensão dos movimentos nacionalistas. Se, no século XVIII, a palavra "raça" era usada para designar uma descendência comum de um conjunto de pessoas e o uso dessa categoria explicava como os seres humanos teriam adquirido as características que os distinguiam, no século XIX, conforme destaca Banton (1979, p. 39):

\footnotetext{
"a raça tornou-se um meio de classificar as pessoas por estas características

[...] as categorizações raciais podiam então ser aplicadas sem adesão a qualquer teoria sobre as origens de tais distinções".
}

Para esse autor, a principal fonte das teorias raciais do século XIX estava no complexo de idéias sobre a pré-história do mundo e a origem das espécies, ainda influenciada pelo estado conjuntural de um conhecimento muito particular sobre os modos de vida dos povos não-europeus e pelo contexto dos contatos raciais no ultramar. A ideologia da direita tradicionalista e contrarevolucionária do final do século XVIII e início do século XIX, tanto quanto as teorias raciais e o dogma racial da desigualdade desse período, rejeitam, de um lado,
"a noção de igualdade como radicalmente incompatível com a sua (da direita) concepção de vida em sociedade, com seu amor a um passado de ordens e privilégios [...]; de outro, assumindo um dado incontornável da natureza - ah, 'as lições da natureza'! -, que todo organismo vivo é diferente e dife- renciado, acoplagem de diferença e hierarquia na mesma proposta, o anti- universalismo com o anti-igualitarismo" (PIERUCCI, 1999, p. 29).

Para Schwartz (1993,1996), o determinismo racial buscava naturalizar as diferenças sociais em sociedades formalmente igualitárias, afirmando que a perfeição abstrata estava na "raça" ariana, último estágio evolutivo do homem, sendo as outras "raças" inferiores à "raça" branca. A partir da noção darwinista de sobrevivência do mais apto, naturalizavam-se questões relativas à ordem social, econômica e política, transformando-as em hierarquias naturais e responsabilizando a natureza pelas desigualdades instituídas pela emergência do capitalismo. O evolucionismo tornou-se o paradigma de uma época e a biologia teve papel fundamental na naturalização da diferença por meio da ciência. Tais visões raciais estavam inseridas em uma ordem sociocultural cujos porta-vozes não tinham dúvidas quanto à propriedade da classificação racial, que colocava os índios abaixo dos brancos e os negros na base de toda a classificação. 
Ao analisar a construção do conhecimento científico racializado, Gould (1993) questiona se a introdução do método indutivo produziu dados legítimos para mudar ou fortalecer tal conhecimento, ou se o compromisso apriorístico com a classificação racial modelou as próprias questões científicas e até mesmo os dados coletados, de modo a sustentar uma conclusão preexistente. Para o autor, no contexto da época, o consenso dos cientistas em torno das classificações convencionais seria conseqüência de crenças sociais compartilhadas e não de dados objetivos coletados para se testar uma hipótese. Assim, os discursos científicos sobre "raça" serviram para sustentar a crença de que grupos raciais distintos existiam entre os seres humanos, legitimando classificações populares e refletindo condições sociopolíticas prevalentes. Gould (1993) assinala que havia um processo de causalidade reversa, no qual pronunciamentos científicos considerados objetivos eram lidos como apoio independente para o contexto político que lhes dava origem.

No século XIX, dois grupos se distinguiam na discussão sobre "raça". De um lado, havia aqueles que acreditavam que os negros eram inferiores e seu status biológico justificava a escravidão e o colonialismo; de outro, aqueles que aceitavam o pressuposto da inferioridade mental ou intelectual dos negros, sem que isto justificasse a perda do direito à liberdade. Este último grupo acreditava que educação e padrão de vida adequados, configurados nos moldes ocidentais, poderiam elevar os negros ao nível dos brancos, uma vez que sua inferioridade era puramente conjuntural e poderia ser erradicada. A crítica à classificação racial não isentava seus autores de afirmações racistas, pois embora protestassem contra as classificações baseadas na beleza ou habilidade mental presumida, não tinham dúvidas quanto ao papel da "raça" branca como padrão a ser alcançado pelas demais.

As justificativas pré-evolucionárias para a classificação racial prosseguiram em dois estilos de racismo científico: o monogenismo e o poligenismo. O monogenismo nivelava todos os povos à unidade da Santa Escritura, a partir da criação de Adão e Eva, e afirmava que as "raças" humanas eram um produto da degeneração da perfeição do Éden, sendo que, dado sobretudo o clima, os brancos tinham declinado menos que os negros. $\mathrm{O}$ poligenismo alegava que a Sagrada Escritura era alegórica e que as "raças" humanas eram espécies biológicas separadas, descendentes de diferentes "adãos". Os negros, como uma outra forma de vida, não deveriam, portanto, participar da igualdade do homem branco civilizado. Entretanto, a interfertilidade de todas as "raças" humanas parecia garantir sua unicidade, como uma espécie, 
definida enquanto uma população de indivíduos capazes de procriar. Cientistas sustentavam que a poligenia não era um ataque à doutrina da unidade do homem, pois embora as "raças" fossem espécies criadas separadamente, os homens estariam unidos por uma estrutura e compaixão comuns. Nem mesmo o advento da teoria da ancestralidade foi vista como uma ameaça às teses poligenistas, pois a teoria de Darwin não apagava as evidências acerca da diversidade humana, nem explicava essas diferenças ou os efeitos da mistura racial (STOCKING JR, 1982).

\section{3. "Raça” e Saúde no Brasil}

No contexto sociopolítico brasileiro de meados do século XIX, o pensamento racial estava relacionado ao liberalismo clássico, que preconizava a abolição de todas as restrições à liberdade individual, entre as quais se incluía a escravidão (SKIDMORE, 1997). No Brasil monárquico, segundo Mattos (2000), a noção moderna de "raça" se fazia mais problemática porque expunha as contradições liberais entre os direitos civis e políticos dos novos cidadãos, os privilégios das elites sociais e políticas do país - que traziam a marca de discriminação herdada do Império português - e os interesses escravistas compartilhados por uma população de pardos livres que reivindicava igualdade entre os cidadãos livres e o silêncio sobre sua própria cor. Cunha (2002) chama a atenção para o fato de que as tentativas de definir, no Brasil, a noção de identidade (da espécie, das raças, dos tipos antropológicos e finalmente dos indivíduos) e a melhor maneira de conceituá-la e apreendê-la na sua singularidade estavam vinculadas a discussões acerca da validade e utilidade das classificações raciais.

A idéia de "raça", em nosso país, agregava idéias baseadas nas teorias raciais norte-americanas e européias e na superioridade da civilização ocidental, com uma discussão sobre a miscigenação e a construção da nação, combinando uma interpretação social darwinista com a perspectiva evolucionista e monogenista (SEYFERTH, 1995). Essa característica do pensamento racial nacional refletia o quadro demográfico do país, no qual a discussão sobre a miscigenação estava presente tanto nos ambientes acadêmicos quanto no cotidiano dos cidadãos. Esse modelo racial sustentava um debate sobre a constituição da nação, explicando as diferenças e hierarquias, assim como a viabilidade de um país mestiço, em que a possibilidade do surgimento de um 
tipo étnico representativo dotaria a nação de uma homogeneidade integradora (FONSECA, 1992).

Para Schwartz (1996), o apego aos modelos raciais se torna mais evidente nos estudos de medicina legal, com o uso de teorias darwinistas sociais nos quais o objeto privilegiado não é mais a doença ou crime, mas o criminoso. Para essa autora, a medicina legal orientava os cientistas acerca da avaliação da especificidade nacional e apontava as possibilidades para uma ciência brasileira que se detivesse nos casos de degeneração racial e seus temores quanto aos riscos da hereditariedade mista. Para os cientistas brasileiros, não havia desacordo quanto à idéia da inferioridade biológica e cultural dos negros. A divergência se colocava na permanência ou transitoriedade da constituição orgânica de uma "raça mestiça", se esta era irreparável ou remediável. A composição étnica e as epidemias - tidas como uma fraqueza biológica das nossas "raças" - impunham desafios aos intelectuais, acerca dos diagnósticos sobre o futuro do Brasil.

No tocante às doenças, o movimento pelo saneamento do Brasil e a reforma da Saúde Pública, encabeçados por médicos-higienistas, a partir de meados da década de 1910, buscaram absolver o país da condenação a uma inferioridade determinada pela sua constituição racial e por seu clima tropical, apontando as endemias rurais como responsáveis pelo atraso social e econômico (LIMA \& HOCHMAN, 1996). Entretanto, como assinala Moutinho (2001), a incorporação, por parte dos cientistas brasileiros, das teorias estrangeiras com relação à mestiçagem não estava isenta de tensões, e a teoria do branqueamento, construída entre o final do Império e a Primeira Guerra Mundial, trazia em si uma ambigüidade, fruto da concepção da mestiçagem como mal e solução. A mestiçagem, sem uma regulação do Estado, poderia ter conseqüências nefastas sobre a formação da nação, mas, se seletiva e controlada, representaria a depuração das características inferiores advindas dos negros e mantidas nos mestiços.

Isto envolvia os pensadores brasileiros naquilo que Skidmore (1997) chamou de uma armadilha determinista, porque esses cientistas viam a miscigenação como fruto de um passado, que tinha condenado a nação a um status de terceira classe, mas vislumbravam no futuro um espaço, caso a redenção étnica fosse de algum modo possível, para manobras políticas de cunho social configuradas para acelerar o desenvolvimento nacional. 
Ao aceitar a teoria racista da superioridade branca, porém rejeitando a teoria das diferenças biológicas absolutas que condenava as populações mistas como degeneradas, os pensadores brasileiros escapavam dessa armadilha, propondo uma ação regeneradora à miscigenação com "raças" européias, se não biológica, ao menos nos termos do contato cultural. Ela inexoravelmente branquearia e elevaria a população, pois a distinção da cor era vista menos pelas características fisiológicas e mais em função da posição sociocultural. A tese branqueadora teve apoio no Brasil devido à crença de que os portugueses branqueavam as populações com as quais eles se misturavam e também por se acreditar que as taxas de reprodução de negros e mulatos eram mais baixas. Garantia, desse modo, que o problema da cor no Brasil iria desaparecer gradual e inevitavelmente, pelo aumento do número de imigrantes europeus, pela miscigenação ou pela falha em se reproduzir dos negros e mulatos.

No Brasil da virada do século XX, a eugenia, ciência do aprimoramento da "raça", oferecia ao país a perspectiva da constituição de indivíduos conformados biologicamente e racialmente - uma "raça" brasileira, construída não apenas pelo branqueamento, mas também pela ordenação genética da população e pela intervenção no curso das doenças perigosas à "raça" (MARQUES, 1994). Até a década de 1920, uma combinação singular de hipóteses climáticas e raciais sustentava teorias de desregramento sexual que explicavam a disseminação de doenças sexualmente transmissíveis, em que negros, índios e brancos alternavam papéis de hiperestésicos sexuais desprovidos de autocontrole (CARRARA, 1997).

Após esse período, a associação entre "raça" e sífilis no nosso país passa a ser atribuída tanto ao comportamento sexualmente excessivo dos brasileiros quanto à herança do passado escravocrata, às altas taxas de incidência nas camadas mais pobres da população, fonte de degeneração racial e degradação moral, e à capacidade destruidora, por meio da hereditariedade mórbida, que essa enfermidade impunha às gerações futuras. Como aponta Carrara (1996, p. 50):

"a sífilis parecia assim corporificar literalmente o tempo, pois inseria nos espaços orgânicos mais íntimos uma história, um passado, cujo peso determinava o presente e delineava o futuro do indivíduo contaminado".

Para esse autor, as características hereditárias e difusionistas imputadas à sífilis por médicos e intelectuais neolamarckistas deslocavam o problema da 
miscigenação para a patologia sexual e rompiam com o caráter quase imutável da degeneração racial brasileira (CARRARA, 2004). Ao atribuir efeitos deletérios da sífilis sobre a descendência, revertia-se o aspecto negativo da miscigenação e apontava-se uma salvação da raça brasileira pela medicina. Cunha (2002, p. 290) sublinha que

\footnotetext{
"miscigenação e sifilização são lados de uma mesma história de dinâmicas compensatórias que envolvem sucessivos processos adaptativos em vários planos. Se nos planos histórico e cultural os encontros de civilizações foram rearranjados nos trópicos, no plano biológico houve um processo combinatório singular".
}

No caso da tuberculose, doença crônica também prevalente nos estratos inferiores da sociedade e constituídos, na sua maioria, por pessoas pretas e pardas, a noção do meio como força degeneradora da raça se sobrepõe à ação de possíveis cargas hereditárias. Aponta Sheppard (2001), na revisão da literatura médica sobre tuberculose publicada no Brasil do período de 1870 a 1940, que os médicos se mostravam ambivalentes quanto à suscetibilidade racial na explicação do aumento da morbi-mortalidade por tuberculose entre os negros, relutando em marginalizar os fatores ambientais, tais como as condições de vida dessas populações, o tempo de exposição que determinada "raça" tinha em relação à doença e sua habilidade em resistir ou combater a infecção com sucesso - um paradigma ambiental baseado na experiência.

A transição entre o racismo científico e as filosofias sócio-ambientalistas (SKIDMORE, 1997), que ocorre no período de entre-guerras, se caracteriza pela luta eugênica centrada nas campanhas sanitárias que procuram combater as doenças que acometem os brasileiros e abastardam as gerações futuras (LIMA \& HOCHMAN, 1996; CARRARA, 2004). Stepan (2004) destaca que, diferentemente do ocorrido na Grã-Bretanha, houve, no Brasil, uma cooperação intrínseca entre o movimento hereditário da eugenia e o movimento do saneamento orientado pelo meio ambiente. Isto seria decorrente, segundo a autora, da indistinção, pelos eugenistas brasileiros, entre cultura e natureza, que os inspirava a imaginar vários tipos de reformas sanitárias que melhorassem a adequação hereditária dos brasileiros e segundo a qual a eugenia seria uma extensão do trabalho heróico de figuras como Oswaldo Cruz e Carlos Chagas.

Concomitantemente, como assinala Moutinho (2001), intelectuais como Gilberto Freire e Sérgio Buarque de Holanda constroem uma visão do Brasil 
em que combinam as influências do trópico na modificação da "raça", as características éticas e genealógicas do colonizador português e o ethos incorporador do catolicismo 4 . Para Peter Fry (2000, p. 89), "Gilberto Freire, tal como seus predecessores, estava interessado tanto na descrição do Brasil quanto na identificação de sua especificidade em relação a outros países, particularmente os EUA", e seu livro Casa Grande e Senzala "era tanto um exercício de construção de nação como uma etnografia histórica". Os malefícios da miscigenação não derivavam da mistura em si, mas das influências do meio físico - dieta insuficiente, vestimenta inadequada e doenças não-diagnosticadas e sem tratamento (especialmente a sífilis) - que atuavam como importantes fatores modificadores da "raça" e responsáveis pela degeneração de um povo.

Segundo Marques (1994), vista pelo viés racista, se poderia questionar quão divergente seriam o discurso eugênico das diferenças dos brasileiros e a solução da miscigenação do movimento culturalista. Cunha (2002) destaca que o modernismo brasileiro, o racialismo e o modelo da ação regenerativa do discurso eugenista compartilhavam da utopia de uma nação moderna construída sobre um corpo racializado

\footnotetext{
"composto de fragmentos diversos, desenhando um organismo em que substâncias e elementos são complementos perceptíveis na sua distintividade se materializa na atenção cotidiana das instituições de cura e correção aos 'indivíduos' e 'brasileiros', parte do 'plasma', do ‘corpo' e da 'alma' nacionais. Corpo e nação perfazem territórios cuja semantização é concomitante. Ao mesmo tempo, são orientados por princípios de racionalidade, higiene e disciplina corporal supostamente universalistas" (CUNHA, 2002, p. 244).
}

O declínio das teorias do racismo científico e a falta de discriminação legal tornavam o Brasil, na visão de seus ideólogos, moralmente superior a outros países, tais como os EUA, onde era praticada a repressão sistemática das minorias. Apesar do anti-racismo científico, o ideal eugenista obteve respaldo entre a elite política até meados da década de 1940. A despeito das manifestações dos intelectuais brasileiros repudiando a política racista de governos estrangeiros, o governo brasileiro mantinha políticas de imigração discriminatória baseadas no pressuposto de que os imigrantes deveriam se identificar com o ethos brasileiro, excluindo aqueles que fossem estranhos ao organismo nacional (MARQUES, 1994; SKIDMORE, 1997; TRINER, 1999). Sheppard (2001, p. 187) assinala que 
"[...] ironicamente, enquanto a maior parte dos brasileiros cultos nos idos de 1930 houvesse negado o racismo científico, os médicos brasileiros pareciam ter descoberto raça como variável importante na medicina, pois nas décadas de 1930 e 1940 as revistas médicas atolaram-se com trabalhos sobre as ditas doenças dos negros”.

Isto pode ser explicado, segundo Carrara (2004), pelo fato de que, nesse período, apesar de estratégias anticoloniais para construção de uma identidade nacional mais positiva terem sido levadas a cabo pelos intelectuais brasileiros, os termos da inferioridade brasileira foram mantidos, e a raça e o sexo continuaram a ser pontos de passagem quase obrigatórios para entender tal inferioridade.

A partir da década de 1990, a raça volta a ser debatida no âmbito da saúde pública, quando o movimento negro, juntamente com o Ministério da Saúde, propõe ações que orientem a formulação de políticas de saúde direcionadas à população brasileira afro-descendente (BRASIL / MS, 2001), reacendendo as discussões sobre o caráter "étnico-racial" de algumas doenças mais prevalentes nessa população. Destaca-se também a publicação da portaria $\mathrm{n}^{\circ} 3.947 / \mathrm{GM}$ (Diário Oficial da União, 14/01/99), que preconizou, a partir de $1^{\circ}$ de janeiro de 1999, a inclusão do campo raça/cor, de acordo com os atributos adotados pelo IBGE, em todos os sistemas e bases de dados do Ministério da Saúde, como dado complementar para o reconhecimento do indivíduo assistido nos sistemas de informação que assim o requererem, permitindo, desse modo, analisar os dados de vigilância epidemiológica e assistência à saúde com um recorte racial.

\section{4. "Raça" e Genética}

No final do século XIX e início do XX, as classificações raciais atendiam às preocupações dos teóricos do darwinismo social acerca da hereditariedade e da miscigenação - origem, para muitos, da degradação racial -, bem como a necessidade de adotar medidas eugênicas para que a mudança biológica estivesse do lado do "progresso" humano (BANTON, 1979; ROSENBERG, 1997; TAPPER, 1999; NOBLES, 2000; OPPENHEIMER, 2001). Além disso, as análises das diferenças no status de saúde entre as "raças", por meio da pesquisa médica, justificava a dominação racial e apoiava ideologias prevalentes de inferioridade racial, obscurecendo, desse modo, as origens sociais das doenças 
e apoiando a manutenção do status quo (JONES, 1993; WILLIAMS et al., 1994; BHOPAL, 1998). A ciência médica, no registro das evidências dessas diferenças, explicava a desigualdade de fato e justificava, através do conhecimento científico, a desigualdade de direito.

Stepan \& Gilman (1993) chamam a atenção para a centralidade do racismo científico na tradição intelectual ocidental e para a ausência de uma crítica permanente desse racismo na ciência hegemônica. A "raça" foi crucial na construção da ciência moderna, definida como masculina e européia na sua abstração, desprendida e objetiva no trato das questões, purgada de controvérsias políticas e morais, e cujos praticantes eram dotados de uma linguagem empírica e neutra de valores para forjar um conhecimento separado dos outros sistemas de saber. Para Gilroy (1998, p. 844),

"a idéia moderna de raça operava nos limites mais estritos do perceptível [...] definia e consolidava tipologias que não podiam ser dissociadas da sua própria tecnologia representacional e dos seus respectivos regimes cognitivo e perceptual".

A transição da história natural para a biologia provocou mudanças no significado do visual e do visível, com a escala da anatomia comparada e o mundo da luz natural sendo recontextualizados pelo advento do microscópio e do artificial. As teorias raciais acompanharam esse processo e o racismo científico proveu uma série de lentes e espelhos, através dos quais a diversidade humana foi compreendida e experimentada ao longo dos séculos XIX e XX. O "avanço" nas descobertas científicas e o desenvolvimento de novas tecnologias no campo da biologia e, mais especificamente, da genética, trouxeram novos instrumentais que serviram para reiterar velhas concepções oriundas desse racismo (DISOTELL, 2000a).

A descoberta dos grupos sangüíneos e das suas principais características (transmissão mendeliana, presença em todos os seres humanos, invariância face às condições ambientais e antigüidade) deu aos cientistas a oportunidade de buscar nesses grupos as chaves para a diferenciação das populações humanas em "raças" (SANTOS, 1996; DISOTELL, 2000a). Todavia, como destaca Santos (1996), o processo de "molecularização" metodológica não foi acompanhado de uma "desracialização" conceitual (aspas do autor), estando a "raça" não mais sob a influência da esfera tipológica-descritiva, mas da genética e do conceito de população. Apesar do início precoce do uso de genes, ou seus 
produtos imediatos, na investigação dos grupos sangüíneos para classificação racial, a pesquisa genética relativa à variação humana não alcançou seu potencial, na primeira metade do século XX, devido ao seu uso por cientistas com propósitos racistas e sua identificação com os programas de limpeza étnica do regime nazi-fascista alemão durante a Segunda Guerra Mundial (DISOTELL, 2000a).

A partir dos anos 1950, as definições de "raça" propostas pelos cientistas basearam-se na idéia de que o conhecimento genético e a mensuração das frequiências dos genes substituiriam os estudos da natureza ou essência das "raças"; e a teoria matemática das distribuições genéticas da população substituiria o sistema lineano de nomenclatura racial (COOPER, 1994). Os estudos dos clines, variações contínuas na freqüência de um traço ao longo de uma área geográfica, foram vistos como substitutos para "raça" na explicação da variação genética entre populações humanas. Entretanto, a compreensão dos clines e a rejeição das topologias raciais dependiam da apreensão da natureza contínua da variação biológica humana, expressa na maioria dos traços (p.ex.: cor da pele, peso, altura).

A diferenciação em "raças" a partir dos clines também não era possível, porque os clines não covariam, mas, ao invés disso, se distribuem em padrões discordantes ao longo do espaço geográfico. Para Livingstone (1993), a variabilidade da frequiência de um gene podia ser mapeada do mesmo modo que a temperatura é descrita em mapas isotérmicos ou a altitude em mapas cartográficos, sem que tal descrição implicasse, de algum modo, uma explicação. Marshall (1993) assegurava que as classificações raciais seriam úteis se refletissem o desenvolvimento filogenético das espécies, porém seria muito difícil derivar uma árvore filogenética dos dados das populações humanas contemporâneas. Para a autora, a imagem de um retículo seria a mais adequada na ilustração da evolução humana, pois as populações não estiveram expostas a diferentes forças evolucionárias e eventos sob completo ou efetivo isolamento genético. Além disso, os estudos mais atuais de genes polimórficos mostraram diferentes frequiências desses genes para várias doenças em diversas populações mundiais, mas tais achados não contribuíam para estabelecer, necessariamente, uma classificação racial.

Os achados do estudo realizado por Lewontin, em 1972 (citado por DISOTELL, 2000b), mostraram que $85 \%$ de toda variação humana podiam ser encontrados entre membros da mesma população; $8 \%$ da variação genética humana adicional poderiam ser encontrados entre populações dentro de um 
mesmo continente e apenas $6 \%$ da variação poderiam ser atribuídos a diferenças entre as principais "raças" humanas, definidas em um sentido tripartite mais amplo (caucasóide, negróide e mongolóide).

O seqüenciamento do genoma humano realizado por uma empresa privada norte-americana, apesar do número reduzido de amostras estudadas, mostrou que a variação era ainda menor $(0,1 \%)$, levantando questionamentos quanto à explicação genética para a existência de diferenças raciais no status de saúde das populações (ANGIER, 2000; GRAVES et al., 2001). Keller (2000) ressalta que, a despeito do avanço da genética molecular nas últimas décadas, ainda restam dúvidas acerca da adequação da informação seqüencial para o entendimento de funções biológicas e o seqüenciamento genômico não é mais um produto final, mas um instrumento para preencher o espaço entre a informação genética e seu sentido biológico. Segundo a autora, o sequienciamento do genoma põe em xeque as noções corriqueiras de determinismo genético e representa um desafio crítico ao próprio conceito de gene.

No tocante à hipótese genética das diferenças raciais em saúde, Goodman (2000) lista os principais pontos conflitantes: 1) a idéia de "raça" é baseada em tipos fixos, ideais e imutáveis, incompatível com a teoria evolucionária; 2) a variação humana é contínua e as frequiências de alelos tende a variar gradualmente e em decorrência da distância geográfica; 3) a variação humana é não-concordante, com traços genéticos variando independentemente de outros traços; 4) a variação genética intragrupo é maior que a variação entre "raças"; 5) não é possível classificar consistentemente os indivíduos pela "raça" devido às mudanças, ao longo do tempo e do lugar, a que estão sujeitas as concepções de cor e de diferenciação biológica; 6) a "raça" difere dos outros métodos-chave para classificação, por comportar uma ampla gama de interpretações potenciais dos processos subjacentes aos fenômenos analisados. Para o autor, são necessários dois erros ou saltos ilógicos para a aceitação da idéia de que diferenças raciais na doença são devidas a diferenças entre as "raças": 1) crença em que a maioria dos fatores biológicos e comportamentais está localizada nos genes e 2) crença em que as "raças" são construtos úteis e reais. Como lembra o autor, a realidade da "raça" não reside em fundamentos biológicos, mas nos processos sociais e políticos que estabelecem, como lemos, os sentidos mais profundos nos fenótipos.

Em contraposição à hegemonia dos modelos genéticos, pesquisas centradas em duas correntes científicas - programação gestacional e eventos/ 
dificuldades na vida - estão trazendo o meio ambiente de volta à cena, acentuando, desse modo, os contrastes entre inato-imutável versus ambiental e mutável-biológico versus social. Alguns estudos epidemiológicos já apontam as implicações biológicas na vida adulta da exposição intra-uterina a ambientes adversos. Como assinala Washburn (1993), uma explicação genética requer a habilidade em controlar os diferentes meios ambientes.

$\mathrm{Na}$ questão específica da desigualdade racial em saúde, segundo Krieger \& Basset (1993), o modelo genético assegura que os negros são inerentemente mais suscetíveis a determinadas doenças; já os modelos ambientais/culturais vêem os negros como vítimas de fatores que oscilam desde a má nutrição até a falta de educação, ou ressaltam o fato de residirem em moradias superlotadas, tendendo a culpabilizá-los por escolherem certos estilos de vida, responsáveis pelas desigualdades na saúde. De acordo com essas autoras, tais modelos analíticos estão seriamente enviesados, tanto na sua essência quanto na sua aplicação. Refletem as ideologias e as políticas que permeiam a teoria e a pesquisa científica, negando ou obscurecendo que a fonte primária das desigualdades entre negros e brancos deve ser encontrada nos processos de produção social da doença sob condições de opressão racial. Ser negro não é, como sugerem esses modelos, geneticamente determinado, nem se define por certo tom de pele, por condições de vida individuais ou pela má escolha de um estilo de vida, mas sim por uma determinada posição em hierarquias sociais conjuntas de "raça" e classe, com a concentração desproporcional dos negros em todos os estratos mais baixos das classes sociais e, conseqüentemente, com sua discriminação racial.

Lee et al. (2001) questionam se a luz refratada através do prisma do conhecimento genômico iluminará explicações diretas da etiologia das doenças, oferecendo soluções simples para a desigualdade em saúde entre grupos populacionais. Ou se, ao contrário, a rotulação de genes mutantes em subpopulações específicas levará à discriminação e à estigmatização. Para os autores, o advento da nova medicina genômica coincidiu com a ressurreição de uma epistemologia genética da diferença entre grupos humanos, uma reificação de conceitos arcaicos de "raça", através dos quais se procura revelar verdades acerca de identidades sociais por meio da genealogia, genetizandoas a partir de diferenças biológicas tidas como inerentes e imutáveis. As críticas às pesquisas genéticas sobre a variação de polimorfismos de nucleosídeos entre populações e indivíduos, acionadas para explicar a incidência e a severidade das doenças no nível molecular (GUTTMACHER \& COLLINS, 2002), apontam 
para um reducionismo genético, que levaria a uma reconceitualização da etiologia da doença. Os genes, ao contrário dos sintomas, tornam-se agora a maneira crítica pela qual a doença é identificada, minimizando a experiência vivida pelos pacientes e fazendo com que a saúde seja medida menos pelas condições físicas da pessoa no presente e mais pelo cálculo do risco de doença no futuro (McDERMOTT, 1998).

Não podemos esquecer que os genes são um dentre os vários fatores que contribuem para a doença. E um teste genético, embora possa determinar a presença ou ausência de genes ou complexos gênicos, não pode determinar se eles resultarão em doenças e desordens associadas, pois um teste circunscreve apenas um conjunto de probabilidades. Ao associarmos marcadores genéticos identificados com doenças a determinados grupos raciais, a "raça" se torna um substituto do fator de risco, e danos potenciais associados com testes genéticos direcionados a segmentos populacionais específicos podem recair sobre grupos socialmente identificáveis, apagando-se a especificidade individual das assinaturas genéticas e fortalecendo a "raça" como fonte de estigma.

A discussão que envolve os estudos genéticos e raça deve estar pautada, fundamentalmente, no escrutínio de seus argumentos e nas implicações éticas que tem a biologia, sob a orientação do reducionismo genético que sustenta que todo comportamento biológico (e social) é no fundo determinado por nossa constituição genética, na conformação de uma visão de mundo. Para Tauber (1999), quando os cientistas se envolvem no debate público sobre questões sociais que irão decidir políticas públicas, sua autoridade está sujeita a diferentes regras de inquirição. Nesses debates, os usos da ciência no contexto social não podem ser neutros e a neutralidade da ciência depende em considerar a natureza como livre de valores, secularizada e desengajada. Os valores estariam enraizados nas necessidades e desejos humanos. Quando os achados da ciência são usados no debate social, sua neutralidade é perdida porque valores humanos são impostos sobre o que, deixado isolado, poderia, de outro modo, alegar objetividade.

\section{5. "Raça" e seu Uso na Pesquisa em Saúde}

Em alguns países, o uso rotineiro da variável "raça" no delineamento e na análise dos fatores de confusão nos estudos epidemiológicos não tem 
garantido, na mesma medida, o questionamento ou a provisão de justificativas explícitas dessas práticas (COMSTOCK et al., 2004). Isto foi constatado por Williams (1994), ao avaliar o modo como "raça" e etnicidade foram usadas em pesquisas sobre serviços de saúde publicadas em 192 artigos da revista Health Services Research, no período de 1966 a 1990. Segundo o autor, 121 (63\%) deles incluíram "raça" ou etnicidade, embora nenhum artigo tenha provido uma definição explícita para os termos. "Raça" e etnicidade foram usados de maneira intercambiável, sem distinção entre nacionalidade, ancestralidade, "raça" e etnicidade. A maioria dos pesquisadores usou "raça" para se referir a fatores sociodemográficos ou socioculturais (pobreza, poder de ganho potencial/risco financeiro, níveis de renda e ocupação), porém seu uso na análise não estava associado a uma justificativa teórica para explicar o fenômeno em questão.

Outra característica do uso da variável "raça" nos estudos epidemiológicos foi revelada por Jones et al. (1991) na análise de 558 artigos epidemiológicos originais publicados na revista American Journal of Epidemiology, no período de 1921 a 1990. Os autores detectaram tendência crescente do uso da variável "raça" como critério de exclusão para os indivíduos não-brancos, limitando a análise para possíveis diferenças raciais.

Pode-se argumentar que a natureza sociopolítica da "raça" não é problemática para a pesquisa em saúde se o que está sendo medido pela variável "raça" é comumente entendido - ou seja, se existe consenso acerca do seu significado. Porém LaVEIST (1994) notou, na consulta a dicionários de epidemiologia, genética, biologia, medicina e psiquiatria norte-americanos, que, nos conceitos expostos por esses documentos, a definição de "raça" se detinha ora à questão biológica (sem entretanto prover diretrizes biológicas rigorosas para identificação das "raças" individuais); ora à soma de categorias usadas atualmente pelas estatísticas oficiais norte-americanas; ora à etnicidade, nacionalidade, tribo e linhagem genealógica ou, finalmente, a um grupo de indivíduos suscetíveis a uma mesma doença. Isto pode resultar em um grau de erro na mensuração da variável "raça" e, mais importante, na ausência de clareza conceitual, deixando um grande espaço para interpretações dos achados da pesquisa que não permitem, assim, formular políticas públicas efetivas.

Para Willis (2001), os processos envolvidos na construção de "raça" são essencialmente similares às construções de gênero, classe ou grupos etários - ou seja, são categorias culturalmente construídas com base na comunicação de diferenças reais ou atribuídas. A existência de distinções fenotípicas entre 
as pessoas e a delimitação de fronteiras grupais ao redor dessas distinções é um fato cujo significado social (e não biológico) torna a "raça" um conceito analítico útil (KAUFMAN \& COOPER, 1995; MANUEL, 2000). Todavia, constata-se que há diversos níveis de abstração quando se concebe o significado social e que não há consenso sobre quantas maneiras a "raça" pode ser categorizada.

Em decorrência disso, Manuel (2000) sugere que os pesquisadores explicitem os conceitos de identidade, consciência, coesão e auto-estima racial, para que não haja ambigüidade conceitual na captura analítica dos processos delimitadores de fronteiras grupais em uma sociedade que se estrutura ao redor de diferenças fenotípicas. Para esse autor, maior atenção, por parte dos pesquisadores, à avaliação dos sentidos específicos vinculados à identidade social ou às estruturas sociais atuais sobre os quais a "raça" se apóia, minimizaria o risco de erros de mensuração que aumentam a variância da variável, levando a coeficientes enviesados, freqüentemente atenuados, na comparação da "raça" com outras variáveis. Tais vieses reduzem a capacidade explanatória da variável "raça", com sérias implicações na definição de políticas ou programas de saúde que buscam minorar as diferenças raciais em saúde de determinados grupos sociais.

LaVEIST (1994) crê que a variável "raça" cobre dois fatores subjacentes diferenciáveis: sociais e étnico-culturais. Os fatores sociais referemse a condições externas ao indivíduo, que variam segundo diferenças raciais em aspectos, tais como o acesso a saneamento e outros serviços públicos, ou na distribuição diferencial no acesso a cuidados médicos de qualidade. Já os fatores étnico-culturais incidem sobre o comportamento individual, tais como as práticas dietéticas, o uso de álcool e tabaco e a resposta a eventos estressantes, estando conectados a determinadas normas culturais. $\mathrm{O}$ autor vê a formulação atual da "raça", no que se relaciona à saúde, como um construto multidimensional, cujo indicador mais freqüentemente destacado é a cor da pele. Por meio desta, algumas pessoas atribuem status racial a outras, alocando-as em categorias que determinam seu nível de exposição a riscos externos à saúde. Vale ressaltar que a classificação racial segundo a tonalidade da pele se estrutura segundo as características particulares da população e de seu contexto urbano e sociocultural (TELLES, 2001; GRAVLEE, 2002). A maneira como coletamos os dados em uma classificação racial baseada na cor da pele pode estar relacionada com o tipo de exposição a riscos à saúde que queremos estudar. Em decorrência 
disso, sugere-se que a variável raça/cor seja atribuída pelo entrevistador, para estimar a exposição social a riscos de saúde, e autoclassificada pelo respondente, para estimar a exposição aos comportamentos de risco atribuídos a fatores culturais.

Segundo Guimarães (2001), o termo "raça" no Brasil, diferente da cor, não é um conceito nativo, usual e de sentido inequívoco, embora já comece a ser adotado por vários grupos sociais. Portanto, o autor recomenda que a melhor maneira de se classificar as pessoas, para fins de pesquisa em "raça", é perguntar "qual a sua cor?" ou "como o sr(a) se classificaria em termos de cor?", ou variações em torno da pergunta sobre cor. Para esse autor, o uso de uma questão aberta para a variável raça/cor é importante porque não há consenso sobre que categorias êmicas (nativas) são usadas. Mas essa abordagem pode levar a uma diversidade de termos relatados pelos entrevistados para definir sua própria cor. Caso o pesquisador opte pela questão fechada, em que o entrevistador classifica o entrevistado utilizando categorias de cor predefinidas, a atribuição fenotípica por terceiros (etic) permitirá comparar dados coletados e os dados gerados pelo IBGE. No entanto, tem-se uma identidade atribuída por outrem e não a identidade subjetiva do indivíduo, obtida pela autoclassificação, podendo haver uma sobreavaliação das desigualdades raciais, em que mestiços ricos se declaram brancos e a diferença entre negros e pardos tende a diminuir (GUIMARÃES, 1996).

A importância do uso de categorias raciais, segundo Williams (1997), reside no fato de que elas capturam uma parte importante da desigualdade e injustiça sociais, refletem o racismo, apontam o avanço econômico e social de grupos populacionais estigmatizados, e ainda por ser a "raça" um princípio organizador fundamental, inclusive para a formação identitária, em sociedades racializadas. Contudo esse uso pode estar comprometido, pelo fato de os pesquisadores considerarem pouco confiáveis os dados relativos à "raça", duvidando da viabilidade de se usar categorias de identificação racial em suas pesquisas. Tais resistências dizem respeito tanto ao emprego e interpretação das categorias raciais, que, dado seu caráter histórico tornariam as comparações difíceis e pouco confiáveis, quanto à não-exclusividade de certas categorias (p.ex.: hispânico nos EUA), além do caráter múltiplo e dinâmico da identificação étnica e racial, do número crescente de pessoas com identidade multirracial e pelos possíveis erros decorrentes da subenumeração diferencial no censo das populações minoritárias (McKENNEY \& BENNET, 1994; WILLIAMS, 1996 e 1997). 
Para contornar tais dificuldades, Williams (1997) recomenda que a "raça" seja avaliada de forma abrangente, movendo-se além da dicotomia branco/negro; que o desenho e a análise estatística dos estudos epidemiológicos levem em consideração as características que distinguem cada grupo racial e que os pesquisadores usem termos para definição das categorias que sejam amplamente reconhecidos por uma grande variedade de pessoas, refletindo as preferências dos respondentes. Para tal, é necessário utilizar variáveis que expliquem as diferenças segundo fatores que delimitam fronteiras raciais, sejam elas a cor da pele, o grupo étnico ou o racismo.

No Brasil, em várias análises sobre desigualdade racial, a preferência pelo uso de dicotomias branco/negro ou branco/não-branco, em que negro e não-branco passam a incluir as categorias preto e pardo utilizadas nos censos e inquéritos oficiais, se deve tanto às demandas do movimento negro em seu processo de construção de uma identidade racial, quanto às limitações estatísticas geradas pelo percentual muito baixo de pessoas que se identificam como pretas naqueles inquéritos, requerendo a agregação de pretos e pardos para a aplicação de testes estatísticos. Há autores que consideram que os indivíduos que se autoclassificam como pretos ou pardos compartilham de uma situação socioeconômica semelhante, tendo como base os indicadores relativos a rendimentos, educação, inserção na força de trabalho, mobilidade social, dentre outros, o que justificaria sua agregação na categoria negro (OLIVEIRA et al., 1985).

Williams et al. (1994) chamam a atenção para o fato de que as pesquisas, embora estimem a magnitude das diferenças étnicas ou raciais, ainda dão pouca atenção às dinâmicas causais que determinam a distribuição diferencial dos problemas de saúde, pré-requisito para o desenvolvimento e direcionamento de programas e serviços efetivos para redução das disparidades observadas. No caso específico do status socioeconômico e "raça", embora estes estejam fortemente relacionados, não são intercambiáveis, e apenas o controle para status socioeconômico não aponta para as estruturas e processos que podem ser responsáveis pelas diferenças raciais observadas (HERMAN, 1996; LILLIE-BLANTON \& LaVEIST, 1996; SMITH, 2000) Além disso, estimativas relatadas sobre um efeito independente de "raça" podem ser enviesadas pelos métodos convencionais de controle do status socioeconômico que levam a um confundimento residual ou a um superajuste das variáveis intermediárias na cadeia causal (KAUFMAN \& COOPER, 1995; KAUFMAN et al., 1997; MORGENSTERN, 1997). 
A fim de corrigir tais erros, os autores alertam para a necessidade de distinguir entre os tipos de co-variáveis relevantes (confundidoras do efeito da "raça", intermediárias na cadeia causal entre "raça" e resultado, e modificadoras do efeito da "raça") na mensuração do efeito de confundimento nas estimativas das diferenças raciais em saúde. Lillie-Blanton \& LaVeist (1996) recomendam aos pesquisadores em "raça"/etnicidade que a avaliação do status socioeconômico individual (p. ex.: educação, ocupação, renda familiar) seja estendida ao meio ambiente social, tendo em vista que o status socioeconômico individual é, em grande medida, uma expressão das oportunidades econômicas e educacionais disponíveis no nível macroinstitucional. Para esses, autores o meio ambiente social se refere tanto aos fatores socioeconômicos individuais (emprego, educação) quanto às condições de trabalho e moradia, às relações sociais dentro da comunidade ou no trabalho e aos arranjos de poder (fortalecimento político, influência e controle individual e comunitário) que, isoladamente ou em combinação com fatores relativos à pessoa, são determinantes potenciais do status de saúde.

Os conceitos de etnicidade, quando presentes na literatura em saúde pública, referem-se às relações entre coletividades que compartilham identidades, tradições religiosas, línguas, sentimentos de pertencimento a um grupo, ancestralidades ou origens geográficas comuns, que convivem no interior de sociedades dominantes, culturalmente hegemônicas e onde tais coletividades vivem a situação de minorias étnicas (SENIOR \& BHOPAL, 1994; McKENZIE \& CROWCROFT, 1994). A discussão sobre o uso de etnicidade, em substituição à "raça", baseia-se na maior flexibilidade da etnicidade para descrever a diversidade de grupos e no seu poder discriminador na estimativa dos riscos associados a uma gama de atitudes culturais e comportamentais, crenças, modos de vida e condições ambientais de moradia (BHOPAL \& DONALDSON, 1998; OPPENHEIMER, 2001; GRAVES et al., 2001). Para esses autores, a autoclassificação étnica de uma pessoa leva em conta linhagens genéticas presentes na sua ascendência e fatores sociais e culturais que são compartilhados com o grupo, sendo melhor do que a classificação racial atribuída por outra pessoa, pois esta seria apoiada em pressupostos apriorísticos baseados em características fenotípicas.

Com a finalidade de contornar possíveis dificuldades no uso da etnicidade nas pesquisas em saúde, Bhopal (1997) faz algumas recomendações: primeiro, que a etnicidade seja percebida como diferente e não um sinônimo da "raça"; segundo, que se explicite a metodologia utilizada para classificação dos grupos 
étnicos; terceiro, que os investigadores reconheçam a influência potencial de seus valores pessoais, incluindo o etnocentrismo; quarto, que sejam consideradas as diferenças socioeconômicas como uma das explicações possíveis para diferenças raciais em saúde; quinto, que sejam consideradas as limitações no poder de generalização da etnicidade, dada sua natureza fluida e dinâmica; e, finalmente, que as observações das variações na doença sejam seguidas por um exame detalhado da importância relativa das influências ambientais, culturais e biológicas.

Quanto aos aspectos operacionais que devem ser levados em conta na elaboração de um instrumento padronizado de coleta de dados sobre etnicidade para o rastreamento de possíveis portadores do traço falciforme, Aspinall et al. (2003) destacam a importância da investigação da ancestralidade/descendência ou origens étnico-familiares como dimensões particulares e mais estáveis da definição de etnicidade, o método de autoclassificação para assinalação da identificação étnica, a associação de questões fechadas com categorias predefinidas e questões abertas na construção da pergunta, a simplicidade na formulação, a confiabilidade e a aceitabilidade das questões sobre etnicidade.

No enfoque sobre discriminação racial e racismo, pouca atenção tem sido dada à conceituação e mensuração desses construtos e à avaliação empírica de suas conseqüências para a saúde de populações minoritárias, embora, conforme assinala Bhopal (1998), vários estudos os apontem como determinantes das disparidades no acesso aos cuidados em saúde. Muntaner (1999) ressalta que o racismo ainda é visto pelos pesquisadores na epidemiologia e na medicina exclusivamente como uma propriedade psicológica de indivíduos, um preconceito irracional, e não como uma ideologia que promove benefícios econômicos e políticos para a "raça" dominante, cujas discriminações racial, econômica e política se caracterizam por um comportamento aberto, quando as evidências apontam a maior importância, nos cenários institucionais, dos comportamentos indiretos e passivos. Marcos referenciais para o racismo, como o desenvolvido por Jones (2000) - que o classifica em institucionalizado, mediado pessoalmente e internalizado - nos parecem úteis para orientar novas hipóteses sobre as bases das diferenças em saúde associadas à "raça" e para definir intervenções efetivas na eliminação dessas diferenças.

Krieger (2000) assinala que os epidemiologistas podem quantificar os efeitos da discriminação na saúde a partir de abordagens no nível individual, de forma direta, usando medidas de auto-relato de discriminação ou indiretamente, 
através dos achados de diferenças nos resultados de saúde entre grupos dominados e dominantes, e no nível populacional, tais como segregação residencial ou representação política. Northridge \& Shepard (1997) sublinham que, apesar das dificuldades na sua mensuração em estudos epidemiológicos, as formas institucionais do racismo, tais como o racismo ambiental, têm sérias consequiências para a saúde de populações étnicas minoritárias. A variável "raça" pode, também, ser expressão determinante de uma experiência de discriminação racial que não é necessariamente uniforme dentro de uma dada categoria racial - por exemplo, os negros de pele mais escura têm mais chance de experimentar discriminação do que os negros de pele mais clara.

Quanto ao uso da cor da pele como marcador para experiências autorelatadas de discriminação, Krieger et al. (1998) afirmam que a cor da pele não deve ser usada isoladamente na análise das relações entre discriminação e saúde. Devem-se levar em conta também a posição socioeconômica, o gênero e as medidas relativas ao manejo individual frente a tratamento injusto. Aos autores que advogam o abandono da variável "raça", alegando que a existência de categorias raciais perpetua e acentua as diferenças raciais e encoraja a fragmentação da sociedade, Thomas (2001) afirma que tal atitude poderia cegarnos quanto aos modos sutis pelos quais o racismo institucional continua a modelar o comportamento dos profissionais de saúde e dos tomadores de decisão, face à desigualdade racial em saúde.

Hahn \& Stroup (1994) afirmam que "raça" e etnicidade, enquanto classificações sociais, apresentam alguns desafios para a saúde pública. Dentre eles, destacam que "raça" e etnicidade são determinantes importantes do acesso a recursos sociais e do status de saúde, portanto seu uso não é apenas uma questão de método científico, mas também de política e de ética. Para os autores, não há consenso, na comunidade científica, quanto à validade do conceito de "raça" - o que é medido como "raça" não é uma característica biológica, mas uma autopercepção para a qual as características fenotípicas podem ser um dentre muitos critérios. Formas de identificação racial, étnica ou por ancestralidade não são suscetíveis aos critérios-padrão de cientificidade, dada a possibilidade de os indivíduos mudarem sua identidade étnico-racial ao longo do tempo e em decorrência de circunstâncias políticas e sociais.

Os pesquisadores em saúde devem ter claro que a classificação por cor está orientada pela idéia de "raça" e, como assinala Guimarães (2001, p. 12), a "raça" é 
"um conceito sociológico, certamente não realista, no sentido ontológico, pois não reflete algo existente no mundo real, mas um conceito analítico nominalista, no sentido de que se refere a algo que orienta e ordena o discurso sobre a vida social".

Para que possamos apreender as múltiplas facetas desse conceito e suas implicações nos gradientes de saúde das populações, é importante incluir nas pesquisas em saúde uma discussão acerca da relevância da coleta de dados sobre "raça" e etnicidade, uma definição das categorias utilizadas, como elas serão analisadas e a mensuração de possíveis confundimentos. No que concerne à coleta dos dados sobre "raça", deve-se combinar diferentes estratégias, tais como a autoclassificação do entrevistado com questões abertas e fechadas (categorias predefinidas), a classificação do entrevistado por atribuição do entrevistador (categorias predefinidas), bem como a inclusão de questões abertas e fechadas sobre etnicidade.

Em resumo, uma compreensão da definição, mensuração e operacionalização das variáveis "raça" e etnicidade é pré-requisito à interpretação apropriada dos resultados da pesquisa relativos às diferenças raciais nos gradientes de saúde das populações, determinando o desenvolvimento de políticas públicas e seus eventuais sucessos (LaVEIST, 1994; SCHULMAN et al., 1995; LaVEIST, 1996). Usadas de forma não-teórica e mecânica, as variáveis "raça" e etnicidade não iluminam as maneiras em que as diferenças raciais são construídas nos níveis micro e macrossociais.

\section{Conclusão}

Atualmente, as pesquisas em "raça" e saúde se defrontam com as quatro possibilidades de posicionamento apontadas por Guimarães (2002) para o movimento anti-racismo: imputar à "raça" uma determinação biológica das qualidades individuais; não acreditar no caráter biológico das "raças", mas atribuir-lhes o papel de organizador da experiência social humana sem chances de desaparecer; tratar as "raças", do ponto de vista científico e social, como construções que precisam ser superadas para que se possa erradicar o racismo e, finalmente, o reconhecimento da inexistência de "raças" biológicas e "a denúncia da constante transformação da idéia de "raça" sob diferentes formas e tropos" (GUIMARÃES, 2002, p. 53). 
A atitude não-racialista, adotada por alguns profissionais de saúde nos debates sobre "raça" e saúde, não é uma garantia de anti-racismo. Esses profissionais devem analisar a "raça", desnaturalizando-a, apontando e criticando as formas, muitas vezes veladas, de racismo científico presentes em protocolos de pesquisa e estudos epidemiológicos.

É um equívoco concluir que, por não se tratar de classificações científicas, mas construídas e reforçadas por normas sociais, a "raça" e a etnicidade sejam de algum modo artificiais ou irreais e, portanto, destituídas de valor nas pesquisas. "Raça" e etnicidade são realidades definidoras porque (1) estão profundamente enraizadas na consciência individual e coletiva e (2) as percepções sociais acerca da "raça"/cor de uma pessoa podem influenciar na disponibilidade, no acesso e inclusive no resultado do cuidado à saúde. Da mesma forma, modo de vida, status socioeconômico e crenças pessoais são determinados por fatores históricos, culturais e políticos que irão influenciar o status de saúde das populações.

Isto não significa negar que as frequiências de certas variantes de alelos de genes mutantes entre pessoas que compartilham de uma origem geográfica ou cultural não possam vir a ter valor científico para as pesquisas em saúde. Entretanto, uma assinalação racial no contexto etiológico de uma doença não apenas contradiz tudo o que se tem aprendido da biologia, da genética e da história, mas também propicia a perpetuação de desigualdades na saúde de populações minoritárias. As pesquisas que equivocadamente assumem a existência de diferenças biológicas inerentes entre pessoas por algumas características físicas podem incorrer no erro de atribuir uma relação causal entre um fenômeno clínico ou fisiológico complexo e aspectos arbitrários da aparência externa, pois é pouco provável que haja associação direta entre uns poucos genes responsáveis por algumas características fenotípicas e a ocorrência de doenças de caráter multigênico ou variações no efeito terapêutico de uma droga.

A importância dos estudos sobre "raça" está em reconhecer que, ao formalizarmos a "raça" ou a etnicidade como um dos meios para a compreensão das relações complexas nas quais fatores socioambientais e biológicos se interrelacionam, constituindo gradientes de saúde entre subgrupos populacionais, estamos avançando tanto no conhecimento sobre as desigualdades em saúde quanto na formulação de políticas públicas mais justas e equânimes. Para tal, a categorização em grupos raciais ou étnicos para a investigação das desvantagens 
sociais, econômicas e ambientais, associada a um risco aumentado de doença e seu uso no monitoramento e formulação das ações para correção de tais desigualdades, exige o emprego de esquemas classificatórios e modelos explicativos que atendam à complexidade das concepções de "raça". Quando se investigam as causas da desigualdade em saúde, é imperativo que o pesquisador se mova para além do individualismo biomédico e esteja ciente tanto dos processos e fatores sociais subjacentes à desvantagem social historicamente produzida, quanto às restrições macrossociais impostas ao comportamento em saúde. Desse modo, evita-se incorrer em afirmações, infelizmente ainda presentes em muitos estudos, que culpam as vítimas e reforçam estereótipos racistas.

Os estudos que correlacionam "raça", etnicidade e saúde devem buscar compreender a vulnerabilidade múltipla a que estão sujeitos determinados segmentos da população e a extensão na qual o status étnico/racial se combina de forma aditiva e interativa com outras categorias de status social, restringindo ou facilitando a exposição a situações de risco à saúde. No campo específico do processo editorial, é importante ressaltar o papel fundamental dos revisores de publicações científicas na educação da comunidade acadêmica acerca dos usos apropriados e inapropriados de "raça" e etnicidade, insistindo para que sejam sempre explicitados os conceitos utilizados e o modo como as variáveis foram coletadas e analisadas nos estudos.

Vale lembrar que mesmo a utilização crítica da "raça" nas pesquisas em saúde não exclui as tensões decorrentes de uma situação paradoxal, inerente à categorização racial, pois, para a formulação de políticas contra a discriminação e injustiça racial, o uso de achados sobre desigualdades raciais em saúde não deixa de se apoiar em categorias oriundas de um discurso racial questionável e de algum modo anacrônico. Em resumo, independentemente de como são estruturados conceitual e discursivamente os sistemas de classificação, as distinções que fazem nunca são neutras ou inócuas.

A grande questão do estudo da "raça" não está na classificação racial, mas na maneira como se constroem as diferenças e os pressupostos assumidos sempre dentro de hierarquias de valor. Devemos ter em mente que os efeitos da "raça" na saúde não são devidos à classificação racial, mas às noções de superioridade inerentes ao racismo, e que as conseqüências psicossociais e econômicas decorrentes do preconceito e da discriminação racial são causas fundamentais da desigualdade em saúde. 
LaVEIST (1996) afirma que, se procurássemos avaliar o grau de erro na mensuração da variável "raça" como medida de biologia, etnicidade ou fatores sociais, constataríamos que a "raça" é um péssimo indicador de biologia, um bom indicador de etnicidade e um indicador muito bom do grau de exposição a fatores sociais.

\section{Referências}

AFSHARI, R.; BHOPAL, R. S. Changing pattern of use of "ethnicity" and "race" in scientific literature. International Journal of Epidemiology, Oxford, v. 31, n. 5, p.1074, 2002. (Letters to the Editor)

ANGIER, N. Do races differ? Not really, DNA shows. The New York Times, 22 de agosto de 2000.

ASPINAL, P. J.; DYSON, S. M.; ANIONWU, E. N. The feasibility of using ethnicity as a primary tool for antenatal selective screening for sickle cell disorders: pointers from the research evidence. Social Science \& Medicine, Oxford, v. 56, n. 2, p. 285-297, 2003.

ASPINALL, P. J. Describing the "white" ethnic group and its composition in medical research. Social Science \& Medicine, Oxford, v. 47, n. 11, p. 1797$1808,1998$.

BANTON, M. A idéia de "raça”. Lisboa: Edições 70, 1979.

BASSETT, M. T. The pursuit of equity in health: reflections on race and public health data in southern Africa. American Journal of Public Health, Washington, v. 90, n. 11, p. 1690-1693, 2000.

BHOPAL, R.; DONALDSON, L. White, European, Western, Caucasian, or what? Inappropriate labeling in research on race, ethnicity and health. American Journal of Public Health, Washington, v. 88, n. 9, p. 297-8, 1998.

BHOPAL, R. Is research into ethnicity and health racist, unsound or important science? British Medical Journal, London, v. 314, n. 7096, p. 1751-1756, 1997.

. Spectre of racism in health and health care: lessons from history and The United States. British Medical Journal, London, v. 316, n. 7149, p. 1970-1973, 1998. 
BRASIL. MINISTÉRIO DA SAÚDE. Manual das doenças mais importantes por razões étnicas na população brasileira afro-descendente. Brasília: Ministério da Saúde, 2001.

CARRARA, S. L. The symbolic geopolitics of syphilis: an essay in historical anthropology. Curare Sonderband, Berlin, v. 12, p. 81-95, 1997.

. Tributo a Vênus. A luta contra a sífilis no Brasil, da passagem do século aos anos 40. Rio de Janeiro: Fiocruz, 1996.

. Estratégias anticoloniais: sífilis, raça e identidade nacional no Brasil de entre-guerras. In: HOCHMANN, G.; ARMUS, D. (Org.). Cuidar, controlar, curar: ensaios históricos sobre saúde e doença na América Latina e Caribe. Rio de Janeiro: Fiocruz, 2004. p. 427-454.

COMSTOCK, R. D.; CASTILLO, E. M.; LINDSAY, S. P. Four-year review of the use of race and ethnicity in epidemiologic and public health research. American Journal of Epidemiology, Baltimore, v. 159, n. 6, p. 611-9, 2004.

COOPER, R. A case study in the use of race and ethnicity in Public Health Surveillance. Public Health Reports, Rockville, v. 109, n. 1, p. 46-52, 1994.

CROW, J. F. Unequal by nature: a geneticist's perspective on human differences. Daedalus, pp. 81-8. Disponível em: http://www.daedalus.amacad.org/issues/ winter2002/Crow.pdf> Acesso em: 2002.

CUNHA, O. M. G. Intenção e gesto: pessoa, cor e a produção cotidiana da (in)diferença no Rio de Janeiro, 1927-1942. Rio de Janeiro: Arquivo Nacional, 2002.

DISOTELL, T. R. Human genomic variation. Genome Biology, London, v. 1, n. 5, p. 2004.1-2004.2, 2000 b.

Molecular anthropology and race. Annals of the New York Academy of Sciences, New York, v. 925, p. 9-24, 2000a.

DYSON, S. M. "Race", ethnicity and haemoglobin disorders. Social Science \& Medicine, Oxford, v. 47, n. 1, p. 121-13, 1998.

FONSECA, A. M. M. Das raças à família: um debate sobre construção da nação. 1992. Dissertação (Mestrado em História) - Instituto de Filosofia e Ciências Humanas, Universidade de Campinas, Campinas, 1992. 
FRY, P. Politics, nationality, and the meanings of "race" in Brazil. Daedalus, Cambridge (MA), v. 129, n. 2, p. 83-118, 2000.

FULLILOVE, M. T. Abandoning "race" as a variable in Public Health Research - an idea whose time has come. American Journal of Public Health, Washington, v. 88, n. 9, p. 1297-1298, 1998.

GILROY, P. Race ends here. Ethnic and Racial Studies, London, v. 21, n. 5, p. 838-847, 1998.

GOODMAN, A. H. Why genes don't count (for racial differences in health). American Journal of Public Health, Washington, v. 90, n. 11, p. 1699-1702, 2000.

GOULD, S. J. American poligeny and craniometry before Darwin. Blacks and Indians as separate, inferior species. In: HARDING, S. (Ed.). The racial economy of science: toward a democratic future. Bloomington: Indiana University Press, 1993. p. 84-115.

GRAVES, J. S.; KITTLES, R. A.; STEPHENS, J. C.; FREEMAN, H. The Gene Media Forum. Race and Health: in genes or injustice? Disponível em: <http://www.genemedia.org/pdfs/RaceandHealth.pdf> . Acesso em: 2001.

GRAVLEE, C. C. Skin colour, blood pressure, and the contextual effect of culture. Trabalho apresentado no annual Meeting of the Society for Applied Anthropology and the Society for Medical Anthropology, Atlanta, GA, Março 6-10, 2002. Disponível em: 〈http://www-personal.umich.edu/ lanceg/ sfaa02.htm>. Acesso em: 2003.

GUIMARÃES, A. S. A. Classes, raças e democracia. São Paulo: Editora 34, 2002.

. Cor, classe e status nos estudos de Pierson, Azevedo e Harris na Bahia: 1940-1960. In: MAIO, M. C.: SANTOS, R. V. (Org.). Raça, Ciência e Sociedade. Rio de Janeiro: Fiocruz, 1996. p. 143-157.

. Racismo e anti-racismo no Brasil. São Paulo: Editora 34, 1999.

. Como trabalhar com "raça" e "classe". Texto apresentado no ciclo de seminários do projeto "Gestão Local, Empregabilidade e Eqüidade de Gênero e "raça": uma experiência de Política Pública na Região do ABC Paulista" - CEBRAP. Disponível em <www.fflch.usp.br/sociologia/asag/ comotrabalharcom"raça"eclasse.pdf >. Acesso em: 2001. 
GUTTMACHER, A. E.; COLLINS, F. S. Genomic Medicine - a primer. New England Journal of Medicine, Boston, v. 347, n. 19, p. 1512-20, 2002.

HAHN, R. A.; STROUP, D. F. Race and ethnicity in Public Health Surveillance: criteria for the scientific use of social categories. Public Health Reports, Rockville, v. 109, n. 1, p. 7-15, 1994.

HASENBALG, C. Entre o mito e os fatos: racismo e relações raciais no Brasil. In: MAIO, M. C.; SANTOS, R. V. (Org.). Raça, Ciência e Sociedade. Rio de Janeiro: Fiocruz, 1996. p. 235-49.

HERMAN, A. A. Toward a conceptualization of race in epidemiologic research. Ethnicity \& Disease, Atlanta, v. 6, n. 1-2, p. 7-20, 1996.

JONES, C. P. Levels of racism: a theoretic framework and a gardener's tale. American Journal of Public Health, Washington, v. 90, n. 8, p. 1212-1215, 2000.

JONES, C. P.; LaVEIST, T. A.; LILLIE-BLANTON, M. "Race" in the epidemiologic literature: an examination of the American Journal of Epidemiology, 1921-1990. American Journal of Epidemiology, Baltimore, v. 134, n. 10, p. 1079-1084, 1991.

JONES, J. H. Bad Blood. The Tuskegee Syphilis Experiment. 2. ed. New York: The Free Press, 1993.

KAUFMAN, J. S.; COOPER, R. S. Descriptive studies of racial differences in disease: in search of the hypothesis. Public Health Report, Rockville, v. 110, n. 6, p. 662-666, 1995.

KAUFMAN, J. S.; HALL, S. A. The slavery hypertension hypothesis: dissemination and appeal of a modern race theory. Epidemiology, Cambridge (MA), v. 14, n. 1, p. 111-118, 2003.

KAUFMAN, J. S. How inconsistencies in racial classification demystify the race construct in Public Health. Epidemiology, Cambridge (MA), v. 10, n. 2, p. 101-103, 1999.

KAUFMAN, J. S.; COOPER, R. S.; MCGEE, D. L. Socioeconomic status and health in blacks and whites: the problem of residual confounding and resiliency of race. Epidemiology, Cambridge (MA), v. 8, p. 6, p. 621-628, 1997.

KELLER, E. F. The Century of the Gene. Cambridge: Harvard University Press, 2000. 
KRIEGER, N.; BASSET, M. The health of black folks. Disease, class and ideology in science. In: HARDING, S. (Ed.). The racial economy of science: toward a democratic future. Bloomington: Indiana University Press, 1993. p. 160-169.

KRIEGER, N. Discrimination and health. In: BERKMAN, L.; KAWACHI, I. (Ed.). Social Epidemiology. Oxford: Oxford University Press, 2000. p. 36-75.

KRIEGER, N.; SIDNEY, S.; COAKLEY, E. Racial discrimination and skin color in the CARDIA Study: implications for public health research. American Journal of Public Health, Washington, v. 88, n. 9, p. 1308-1313, 1998.

LaVEIST, T. A. Beyond dummy variables and sample selection: what health services researchers ought to know about race as a variable. Health Services Research, Chicago, v. 29, n. 1, p. 1-16, 1994.

. Why we should continue to study race... but do a better job: an essay on race, racism and health. Ethnicity \& Disease, Atlanta, v. 6, n. 1-2, p. 21-29, Winter-Spring 1996.

LEE, S. S-J.; MOUNTAIN, J.; KOENIG, B. A. The meanings of "race" in the new genomics; implications for health disparities research. Yale Journal of Health Policy, Law \& Ethics, New Haven, v. 1, p. 33-75, Spring 2001.

LILLIE-BLANTON, M.; LaVEIST, T. Race/ethnicity, the social environment, and health. Social Science \& Medicine, Oxford, v. 43, n. 1, p. 83-91, 1996.

LILLIE-BLANTON, M.; PARSONS, P. E.; GAYLE, H.; DIEVLER, A. Racial differences in health: not just Black and White, but shades of gray. Annual Review of Public Health, Palo Alto, v. 17, p. 411-448, 1996.

LIMA, N. T.; HOCHMAN, G. Condenado pela raça, absolvido pela medicina: o Brasil descoberto pelo movimento sanitarista da Primeira República. In: MAIO, M. C.; SANTOS, R. V. (Org.). Raça, Ciência e Sociedade. Rio de Janeiro: Fiocruz, 1996. p. 23-40.

LIVINGSTONE, F. B. On the nonexistence of human races In: HARDING, S. (Ed.). The racial economy of science: toward a democratic future. Bloomington: Indiana University Press, 1993. p. 133-141.

MAGGIE, Y. "Aqueles a quem foi negada a cor do dia": as categorias cor e raça na cultura brasileira. In: MAIO, M. C.; SANTOS, R. V. (Org.). Raça, Ciência e Sociedade. Rio de Janeiro: Fiocruz, 1996. p. 225-34. 
MANUEL, R. C. The conceptualization and measurement of race and beyond. African American Research Perspectives, 6, 2000. Disponível em: <www.rcgd.isr.umich.edu/prba/perspectives/ springsummer2000/rmanuel2.pdf >. Acesso em: 2001.

MARQUES, V. R. B. A medicalização da "raça": médicos, educadores e discurso eugênico. Campinas: UNICAMP, 1994.

MARSHALL, G. A. Racial classifications: popular and scientific. In: HARDING, S. (Ed.). The racial economy of science: toward a democratic future. Bloomington: Indiana University Press, 1993. p. 116-127.

MATTOS, H. M. Escravidão e cidadania no Brasil monárquico. Rio de Janeiro: Jorge Zahar, 2000.

McDERMOTT, R. Ethic, epidemiology and the thrifty gene: biological determinism as a health hazard. Social Science \& Medicine, Oxford, v. 47, n. 9, p. 1189-1195, 1998.

McKENNEY, N. R.; BENNET, C. E. Issues regarding data on race and ethnicity: The census Bureau Experience. Public Health Reports, Rockville, v. 109, n. 1, p. 16-25, 1994.

McKENZIE, K. J.; CROWCROFT, N. S. Race, ethnicity, culture, and science. British Medical Journal. London, v. 309, n. 6950, p. 286-287, 1994.

MORGENSTERN, H. Defining and explaining race effects. Epidemiology, Cambridge (MA), v. 8, n. 6, p. 609-610, 1997.

MOUTINHO, L. Razão, "raça" e desejo: uma análise comparativa sobre relacionamentos afetivo-sexuais "inter-raciais" no Brasil e na África do Sul. 2001. Tese (Doutorado em Sociologia e Antropologia) - Instituto de Filosofia e Ciências Sociais, Universidade Federal do Rio de Janeiro, Rio de Janeiro, 2001.

MUNTANER, C. Social Mechanisms, race, and social epidemiology. American Journal of Epidemiology, Baltimore, v. 150, n. 2, p. 121-126, 1999.

NOBLES, M. History counts: a comparative analysis of racial/color categorization in US and Brazilian censuses. American Journal of Public Health, Washington, v. 90, n. 11, p. 1738-1745, 2000.

NORTHRIDGE, M. E.; SHEPARD, P. M. Environmental racism and Public Health. American Journal of Public Health, Washington, v. 87, n. 5, p. 730$732,1997$. 
OLIVEIRA, L. E. G; PORCARO, R. M.; ARAÚJO, T. C. N. O lugar do negro na força de trabalho. Rio de Janeiro: IBGE, 1985.

OPPENHEIMER, G. M. Paradigm lost: race, ethnicity, and the search for a new population taxonomy. American Journal of Public Health, Washington, v. 91, n. 7, p. 1049-1055, 2001.

PENA, S. D. J.; CARVALHO-SILVA, D. R.; ALVES-SILVA, J.; PRADO, V. F.; SANTOS, F. R. Retrato molecular do Brasil. Ciência-Hoje, v. 27, n. 159 , p. 16-25, 2000.

PFEFFER, N. Theories of race, ethnicity and culture. British Medical Journal, London, v. 317, n. 7169, p. 1381-84, 1998.

PIERUCCI, A. F. Ciladas da diferença. São Paulo: Editora 34, 1999.

RAMOS, J. S. O Brasil sob o paradigma racial: sociologia histórica de uma representação. In: PENA, S. D. J. (Org.). Homo brasilis. Aspectos genéticos, lingüísticos, históricos e socioantropológicos da formação do povo brasileiro. Ribeirão Preto: FUNPEC-RP, 2002. p. 131-48.

ROSENBERG, C. E. No other gods. On science and American social thought. Baltimore: The Johns Hopkins University Press, 1997.

SANTOS, R. V. Da morfologia às moléculas, de raça à população: trajetórias conceituais em antropologia física no século XX. In: MAIO, M. C.; SANTOS, R. V. (Org.). Raça, Ciência e Sociedade. Rio de Janeiro: Fiocruz, 1996. p. 125-140.

SATEL, S. Medicine's race problem. Policy Review, 110, December 2001/ January 2002. Disponível em: <http://www.policyreview.org/DEC01/>. Acesso em: 2002.

SCHULMAN, K. A.; RUBENSTEIN, E.; CHESLEY, F. D.; EISEMBERG, J. M. The role of race and socioeconomic factors in health services research. Health Services Research, Chicago, v. 30, n. 1-2, p. 179-195, 1995.

SCHWARTZ, L. M. As teorias raciais, uma construção histórica de finais do século XIX. O contexto brasileiro. In: SCHWARTZ, L. M.; QUEIROZ, R. S. (Org.). Raça e Diversidade. Queiroz: EDUSP, 1996. p. 147-185.

O espetáculo das raças. Cientistas, instituições e questão racial no Brasil 1870-1930. São Paulo: Companhia das Letras, 1993. 
SCHWARTZ, R. S. Racial profiling in medical research. New England Journal of Medicine. Boston, v. 344, n. 18, p. 1392-1 393, 2001.

SENIOR, P. A.; BHOPAL, R. Ethnicity as a variable in epidemiological research. British Medical Journal, London, v. 309, n. 6950, p. 327-330, 1994.

SEYFERTH, G. A invenção da raça e o poder discricionário dos estereótipos. Anuário antropológico, v. 93, p. 175-203, 1995.

SHEPPARD, D. S. A literatura médica brasileira sobre a peste branca: 18701940. História, Ciências e Saúde, Rio de Janeiro, v. 8, n. 1, p. 172-92, 2001.

SHRIVER, M. D. Ethnic variation as a key to the biology of human disease. Annals of Internal Medicine, Philadelphia, v. 127, n. 5, p. 401-403, 1997.

SKIDMORE, T. E. Racial ideas and social policy in Brazil, 1870-1940. In: GRAHAM, R. (Ed.). The idea of race in Latin America, 1870-1940. Austin: University of Texas Press, 1997. p. 7-36.

SMITH, G. D. Learning to live with complexity: ethnicity, socioeconomic position, and health in Britain and The United States. American Journal of Public Health, Washington, v. 90, n. 11, p. 1694-1698, 2000.

STEPAN, N.; GILMAN, S. L. Appropriating the idioms of science. The rejection of scientific racism. In: HARDING, S. (Ed.). The racial economy of science: toward a democratic future. Bloomington: Indiana University Press, 1993. p. 170-193.

WILLIAMS, D. R.; LAVIZZO-MOUREY, R.; WARREN, R. C. The concept of race and health status in America. Public Health Reports, Rockville, v. 109, n. 1, p. 26-41, 1994.

WILLIS, D. P. Them and us: The politics of population taxonomy. American Journal of Public Health, Washington, v. 91, n. 7, p. 1048-9, 2001.

WITZIG, R. The medicalization of race: scientific legitimization of a flawed social construct. Annals ofInternalMedicine, Philadelphia, v. 125, n. 8, p. 675$679,1996$.

STEPAN, N. Eugenia no Brasil, 1917-1940. In: HOCHMANN, G.; ARMUS, D. (Org.). Cuidar, controlar, curar: ensaios históricos sobre saúde e doença na América Latina e Caribe. Rio de Janeiro: Fiocruz, 2004. p. 331-391. 
STOCKING Jr, G. W. Race, culture, and evolution. Essays in the history of Anthropology. Chicago: The Chicago University Press, 1982.

TAPPER, M. In the Blood: sickle cell anemia and the politics of race. Philadelphia: University of Pennsylvania Press, 1999.

TAUBER, A. I. Is biology apolitical science? Bioscience, v. 49, p. 479-86, 1999.

TELLES, E. E. Racial ambiguity among the Brazilian population. Working Paper Series n. 12, Los Angeles: California Center for Population Research/ UCLA, 2001. Disponível em: <http://www.sscnet.ucla.edu/soc/faculty/telles/ Paper_RacialAmbiguityBrazil.pdf >. Acesso em: 2002.

THOMAS, S. B. The color line: race matters in the elimination of health disparities. American Journal of Public Health, Washington, v. 91, n. 7, p. 1046-1055, 2001.

TODOROV, T. Nós e os outros. A reflexão francesa sobre a diversidade humana. Rio de Janeiro: Jorge Zahar, 1993. v.1

TRINER, G. D. Race, with or without color? Reconciling Brazilian historiography. Estudios Interdisciplinarios de America Latina y Caribe, v. 10, n. 1, p. 1-21, 1999.

WASHBURN, S. L. The study of race. In: HARDING, S. (Ed.). The racial economy of science: toward a democratic future. Bloomington: Indiana University Press, 1993. p. 128-132.

WIEVIORKA, M. El espacio del racismo. Barcelona: Paidós, 1992.

WILLIAMS, D. R. Race and health: basic questions, emerging directions. Annals of Epidemiology, Atlanta, v. 7, n. 5, p. 322-333, 1997.

. Race/ethnicity and socioeconomic status: measurement and methodological issues. International Journal of Health Services, Amityville, v. 26, n. 3, p. 483-505, 1996.

. The concept of race in Health Services Research: 1966 to 1990.Health Services Research, Chicago, v. 29, n. 3, p.261-274, 1994.

WILLIAMS, D. R.; LAVIZZO-MOUREY, R.; WARREN, R. C. The concept of race and health status in America. Public Health Reports, Rockville, v. 109, n. 1, p. 26-41, 1994. 
WILLIS, D. P. Them and us: The politics of population taxonomy. American Journal of Public Health, Washington, v. 91, n. 7, p. 1048-9, 2001.

WITZIG, R. The medicalization of race: scientific legitimization of a flawed social construct. Annals ofInternalMedicine, Philadelphia, v. 125, n. 8, p. 675$679,1996$.

\section{NOTAS}

${ }^{1}$ Doutorando da Escola Nacional de Saúde Pública (ENSP).E-mail: josue_laguardia@yahoo.com.br

${ }^{2} \mathrm{O}$ uso de aspas toma em consideração que a noção de "raça" deve ser compreendida como construção local, histórica e culturalmente determinada.

${ }^{3}$ Para uma discussão mais aprofundada, ver Fonseca (1992), Fry (1995 e 2001), Hasenbalg (1996), Guimarães (1999 e 2002) e Ramos (2002).

${ }^{4}$ Segundo Pena et al. (2000, p. 25), os achados de seus estudos filogeográficos com uma amostra de brasileiros brancos de classe média e média alta "dão respaldo científico a essa noção [da natureza triíbrida da população brasileira] e acrescentam um importante detalhe: a contribuição européia foi basicamente através de homens e a ameríndia e africana foi principalmente através de mulheres". Os autores apontam para a grande relevância social da presença de $60 \%$ de matrilinhagens ameríndias e africanas, assinalando que se os brancos brasileiros "que têm DNA mitocondrial ameríndio ou africano se conscientizassem disso valorizariam mais a exuberante diversidade genética do nosso povo, e quem sabe, construiriam no século 21 uma sociedade mais justa e harmônica" (idem). Chama atenção nesse estudo a atualização, por meio de métodos sofisticados de análise genética e de uma terminologia biológica mais moderna, que substitui raça por origem geográfica, de uma visão compartilhada por Paulo Freyre e Edgar Roquette-Pinto (CUNHA, 2002), de que os brasileiros resultam num tipo peculiar de combinação, um tipo étnico - reiterando a imagem de uma nação mestiça e democrática nos seus genes. 


\section{ABSTRACT}

The use of the "race" variable in health research

Recent years have witnessed growing interest in the use of racial and ethnic categories in public health. However, this interest has not been accompanied by a more in-depth discussion of the theoretical and practical problems related to the utilization of the "race" variable. Although the biological concept of "race" still holds a strong appeal among health researchers, various studies have proposed other forms of defining the concept and applying it to health research. This article seeks to outline the analytical implications of the different definitions and uses of "race" and ethnicity in health research, besides identifying its limits and potentials.

Key words: "Race"; ethnicity; health research.

Recebido em: 1\%/10/2004.

Aprovado em: 04/11/2004. 